\title{
Fusarium pallidoroseum: A potential entomopathogenic agent for the biological management of Aphis gossypii
}

\author{
Ritu Srivastava \\ Biocontrol Laboratory, Department of Botany, University of Lucknow, Lucknow- 226007 \\ (U.P.), India
}

\section{Amritesh Chandra Shukla*}

Biocontrol Laboratory, Department of Botany, University of Lucknow, Lucknow- 226007 (U.P.), India

*Corresponding author. Email: amriteshcshukla@gmail.com

\section{Article Info}

https://doi.org/10.31018/ jans.v13i2.2687

Received: April 24, 2021

Revised: June 7, 2021

Accepted: June 10, 2021

\section{How to Cite}

Srivastava, R. and Shukla, A. C. (2021). Fusarium pallidoroseum: A potential entomopathogenic agent for the biological management of Aphis gossypii. Journal of Applied and Natural Science, 13(2), 775 - 785. https://doi.org/10.31018/jans.v13i2.2687

\begin{abstract}
With rising need of switching over to sustainable agricultural practices, utilization of entomopathogenic fungi (EPF) as biocntrol agents, provides better substitute against chemical pesticides- having several side-effects. Therefore, an attempt have been made to explore the potential EPF fungi that could be incorporated into IPM practices for control of Helicoverpa armigera Hubner and Aphis gossypii Glover. Regarding this, an entomopathogenic fungus, Fusarium pallidoroseum (Cooke) Sacc, was isolated from natural population of $H$. armigera infesting chickpea (Cicer arietinum L.) and explored efficacy under in-vitro \& field conditions. The findings of present investigation shows efficacy of $F$. pallidoroseum as potential biocontrol agent against okra aphid (A. gossypii), as it inflicted initial mortality of $43.33 \%$ nymphs on $2^{\text {nd }}$ day and lead to complete annihilation (93.33\%) of nymph population on 8th day of spore suspension application at $1 \times 10^{10}$ spores $/ \mathrm{mL}$ concentration. The observations against adult okra aphid clearly demonstrated that spraying of $1 \times 10^{10} \mathrm{spores} / \mathrm{mL}$ of $F$. pallidoroseum resulted $66.67 \%$ mortality after 8th days of spraying. Increased mortality was recorded with increase in spore suspension concentrations. The LC $C_{50} \& L_{90}$ value for $F$. pallidoroseum against nymphs of $A$. gossypii was recorded $3.79 \times 10^{5}$ and $2.74 \times 10^{8}$, respectively. The findings were used to develop formulations $\left(1 \times 10^{4}\right.$ to $1 \times 10^{10}$ spore suspension $/ \mathrm{mL}$ conc), and tested at field-level. The results showed that formulation at $1 \times 10^{10}$ spores $/ \mathrm{mL}$ conc was most effective against $A$. gossypii, recorded $93.33 \%$ mortality of nymphs \& $66.67 \%$ mortality of adults; could be used under IPM practices.
\end{abstract}

Keywords: Aphis gossypii, Bio-efficacy, Entomopathogen, Fusarium pallidoroseum, Helicoverpa armigera, Bioagent

\section{INTRODUCTION}

During the last few years, $H$. armigera and $A$. gossypii are considered serious pests causing considerable losses under changing agro-climatic conditions in India, despite heavy uses of chemical pesticides (EPPO, 2006; Patel and Purohit, 2013; Ghosal et al., 2012; Khating et al., 2016; Nagamandla et al., 2017; Singh and Dhiman, 2018; Rathee and Dalal, 2018 and Yaqoob et al., 2019). A. gossypii (Homoptera: Aphididae) is a major sucking pest of okra, causing considerable losses in the form of curling and distortion of the young leaves. Also, the presence of nymphs and adults, their shed skins and honeydews decrease the aesthetic quality of the crop. Advancement in the field of biological management of major pests of pulses, especially against the pod borer $H$. armigera, has been significantly in the recent past (Mehrvar et al., 2008; Ahmad and Ansari 2013; Jarrahi and Safavi 2016; Mora et al., 2017; Kalvnadi et al., 2018 and Goncalves et al., 2020). Productivity of chickpea crop is greatly affected by chickpea pod borer $H$. armigera, which damages up to $90-95 \%$ crop because of its high fecundity, nomadic behavior, polyphagous feeding nature and induced resistance against major groups of insecticides (Mishra et al., 2013). This pod has reported the yield loss of up to $400 \mathrm{Kg} / \mathrm{ha}$ - borer, with $30-40 \%$ average pods damaged during favorable environment conditions; which causes reluctant to cultivate chickpea among the farmers (Hussain, 2007).

However, the continued development of natural populations resistant to chemical insecticides indicates that 
further chemicals and or biological agents must be investigated for their efficacy against these insects. Considering the ill effects of chemicals and increased application costs, the biocontrol method such as use of fungal pathogens is desirable. Although, there were lots of evidence on the occurrence and efficacy of entomopathogens such as Metarrhizium spp and Beauveria spp, still there are several gaps in the identification and morphological characterization of natural enemies and their exploitation as bio-management tools with reference to agro-climatic niches. These fungal bio-control agents would offer a new approach to combat natural population of insect pest, while protecting the efforts and investments of the marginal farmers (Pawar and Borikar, 2005; Lingappa et al., 2005; Ahmad and Ansari 2013; Jarrahi and Safavi 2016; Kalvnadi et al., 2018; Mohammed et al. 2018; Javed et al. 2019; Nazir et al. 2019 and Litwin et al. 2020). The indispensable step in the development of an effective fungal microbial biocontrol agent is careful assessment and selection of the most suitable isolate, based on virulence against host insect. Factors such as temperature, $\mathrm{pH}$, humidity and other environmental factors have a great significance in the incidence, severity and epidemiology of the disease (Patel and Purohit, 2013; Khating et al., 2016; Nagamandla et al., 2017; Singh and Dhiman, 2018; Rathee and Dalal, 2018 and Yaqoob et al., 2019). The absence of significant correlation between field and laboratory outcomes have made it complicated to visualize the genuine efficacy of entomopathogen against target and non-target insects due to different environmental conditions. Thus in the present investigation, an attempt have been made to explore an alternate entomopathogenic biocontrol agent from natural environment; which could be used as an eco-friendly, efficient, costeffective biocontrol agent as well as can reduce the agricultural losses.

\section{MATERIALS AND METHODS}

\section{Study area}

Nineteen villages of the Tehsil Bakshi Ka Talab (BKT), district Lucknow; were randomly selected for collection of the diseased Helicoverpa larvae. Bakshi Ka Talab is geographically located at the North Latitude $26^{\circ} 59^{\prime} 0$ and East Latitude $80^{\circ} 53^{\prime} 0^{\prime \prime} \mathrm{E}$. It is situated at the distance of $25 \mathrm{~km}$ away from the Lucknow, at the National Highway 24. The temperature of this area was $42^{\circ} \mathrm{C}$ to $45^{\circ} \mathrm{C}$ while in winter season temperature fell down between $5^{\circ} \mathrm{C}-8^{\circ} \mathrm{C}$ and the elevation of BKT was $124 \mathrm{~m}$ (407 ft). Total number of villages in this Tehsil was 185 (Fig. 1).

\section{Collection of infected Helicoverpa armigera larvae}

Frequent field visits were made to the selected villages of BKT, and collected the diseased specimens of Heli- coverpa larvae. The samples thus collected were kept properly and brought to the Biocontrol Laboratory, University of Lucknow; for further identification of natural enemies.

\section{Isolation of entomopathogenic fungi}

The infected larvae were surface sterilized with $0.1 \%$ $(w / v)$ mercuric chloride solution and rinsed thrice in sterile distilled water. The sterilized infected larva was placed separately into sterilized petriplates, containing potato dextrose agar with streptomycin sulphate $(2.5 \mu \mathrm{g} /$ $\mathrm{mL}$ ), for isolation of entomopathogenic fungi at $28 \pm 2^{\circ} \mathrm{C}$ for three days. The culture was further purified by growing single spore on PDA plates and maintained at $4{ }^{\circ} \mathrm{C}$ in refrigerator.

\section{Effect of different media on isolated entomopathogen}

The isolated entomopathogenic fungus was further cultured on a different medium such as Czapek-Dox agar, potato dextrose agar, MYEA, agar, coconut milk agar (5 and $10 \%$ ), Martin agar medium, Molish Agar medium, Sabarouds agar medium, Richards medium and Asthana and Hawkers medium; for detailed study of morphological characteristics. A mycelial disc of $3 \mathrm{~mm}$ diameter was transferred and inoculated centrally onto different culture plates containing different medium in 3 replicates and incubated at $28 \pm 2^{\circ} \mathrm{C}$. The colony appearances and pigmentations were assessed after 2 weeks of incubation, while growth rate was measured daily until fully grown. Average dry weight of the three replicate was taken as standard value for comparing the growth in different media.

\section{Effect of temperature and $\mathrm{pH}$ on isolated pathogen}

The effect of temperature and $\mathrm{pH}$ was assessed by analyzing the in vitro growth rate on potato dextrose broth at different temperature and $\mathrm{pH}$, respectively. For observing temperature effect, the PDB containing flasks were inoculated with an equal amount of fungal inoculum $(20 \mu$ l of test entomopathogen at the concentration $10^{6}$ spores $/ \mathrm{mL}$ ). The flasks were incubated at different temperatures $20,24,28,32,35$ and $40{ }^{\circ} \mathrm{C}$ after inoculation for fifteen days. The dry weight of mycelial mats was measured 15 days after inoculation.

For observing $\mathrm{pH}$ effect, before sterilization the $\mathrm{pH}$ of the medium was adjusted in the range of $\mathrm{pH}-5$ to $\mathrm{pH}-9$ by using $1 \mathrm{M}$ solution of $\mathrm{HCl}$ and $\mathrm{NaOH}$. The flasks were inoculated with mycelial disc $(3 \mathrm{~mm})$ of entomopathogen from the 7 days old culture. Flasks containing PDB of different $\mathrm{pH}$ were incubated at $28 \pm 2^{\circ} \mathrm{C}$. Average dry weight of the three replicates was taken as standard value for comparing the growth of fungus at different $\mathrm{pH}$.

\section{Scanning electron microscopy}

For SEM observations, mycelia and conidia of F. palli- 
doroseum were fixed with $5 \%$ cold buffered glutaraldehyde for $24 \mathrm{~h}$ at room temperature. The samples were washed with sodium cacodylate buffer for $30 \mathrm{~min}$ and subsequently fixed with $2 \%$ osmium tetraoxide for $24 \mathrm{~h}$ at $20{ }^{\circ} \mathrm{C}$, dehydrated in a graded ethanol series for five minutes each and sputter coated with gold palladium. The images of $F$. pallidoroseum were obtained in the scanning electron microscope (JOEL, Japan, ModelJSM 6490 LV) at the Department of Environmental Science, Babasaheb Bheemrao Ambedkar University, Lucknow. The details regarding applied voltage, magnification used and the size of the content of the images were implanted on the photographs itself.

\section{In vitro bio-efficacy against Helicoverpa armigera and Aphis gossypii}

Two hundred $\mathrm{mL}$ of culture medium was taken in a 500 $\mathrm{mL}$ conical flask, autoclaved at $120{ }^{\circ} \mathrm{C}(15 \mathrm{lbs})$ for 20 minutes. The flasks were inoculated with a six $\mathrm{mm}$ disc of two week's old $F$. pallidoroseum grown on PDA media. The flasks were incubated at $28 \pm 2{ }^{\circ} \mathrm{C}$ in an incubator orbital shaker at $120 \pm 10 \mathrm{rpm}$. The spore suspension was prepared by mixing the fungal mat in a mixergrinder and mixed with $10 \mathrm{ml}$ of sterile distilled water having $0.02 \%$ Tween 80 as a wetting agent (Rombach et al., 1986). The suspension was then filtered through sterile muslin cloth to eliminate the medium (Sasidharan and Varma, 2005). From the stock spore suspension, serial dilutions were made to obtain the require concentrations by using haemocytometer. Spore concentrations of $1 \times 10^{10}, 2 \times 10^{9}, 2 \times 10^{8}, 2 \times 10^{7}$, $2 \times 10^{6}, 2 \times 10^{5}, 2 \times 10^{4}$ and water spray as control were evaluated against $H$. armigera and $A$. gossypii, respectively (Shophiya et al., 2014 and Jayasimha et al., 2012). The lethality of the concentration was recorded by observing the percentage mortality of the okra aphid; at regular interval of two, four, six and eight days, after spraying.

\section{Statistical analysis}

Data on effect of temperature and $\mathrm{pH}$ on the growth of fungus were subjected to ANOVA, using Statistical Analysis System Version 9.0 (SAS 2002); however, for mortality data, Abbot's formula was used to calculate corrected mortality. From the corrected mortality data, the probability integral of the chi square distribution, regression equation, slope and lethal concentrations ( $\mathrm{LC}_{50}$ and $\mathrm{LC}_{90}$ ) were calculated; so that the efficacy and accuracy of the $F$. pallidoroseum can be standardized as an effective entomopathogen.

\section{RESULTS AND DISCUSSION}

During Rabi season; diseased Helicoverpa larvae were collected from chickpea crop of the vegetable growing areas of the study site - Bakshi Ka Talab block, Lucknow district. The samples thus collected were subjected for detailed in vitro investigation at the Bioconrol Laboratory, Department of Botany, University of Lucknow.

Out of total 1250 larvae collected from fields, 32\% mortality was recorded due to tachnid flies, Campoletis chlorideae, nuclear polyhedrosis virus and fungal infection. F. pallidoroseum was isolated from third instar infected larvae of $H$. armigera for the first time in agroclimatic condition of Lucknow district of Uttar Pradesh, India.

\section{Microscopic characteristics}

The isolated fungus showed growth of dense, compact aerial mycelia, initially yellowish-orange colour and later turned white on potato dextrose medium (Fig. 2).

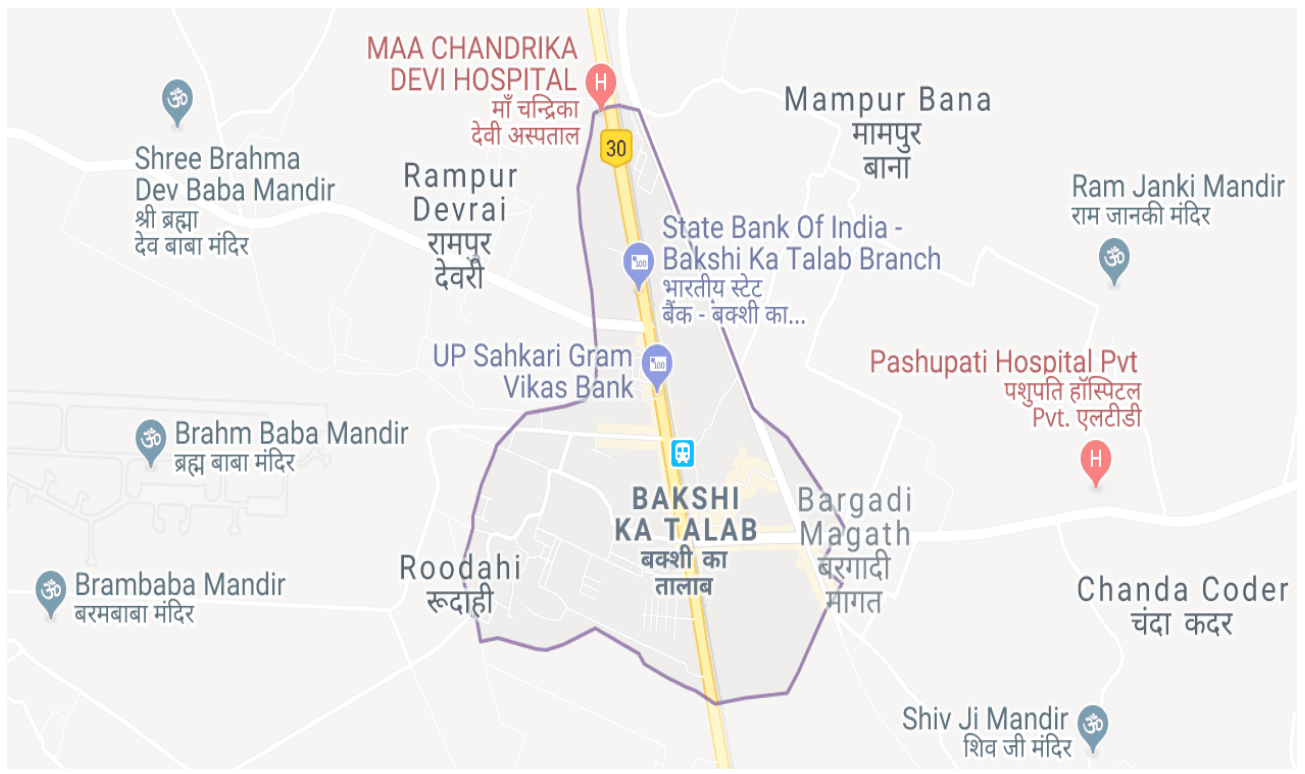

Fig. 1. Study area- Bakshi Ka Talab, Lucknow. 


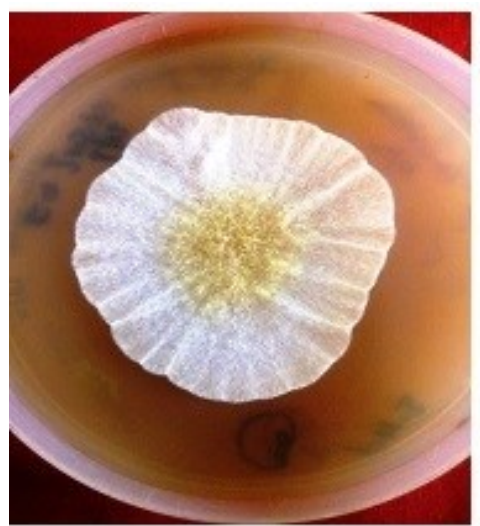

(A)

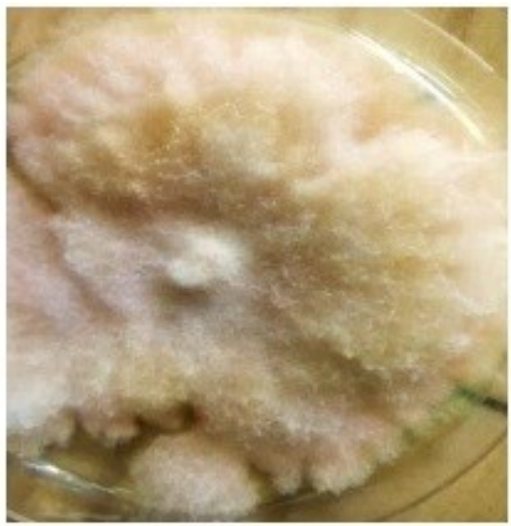

(B)

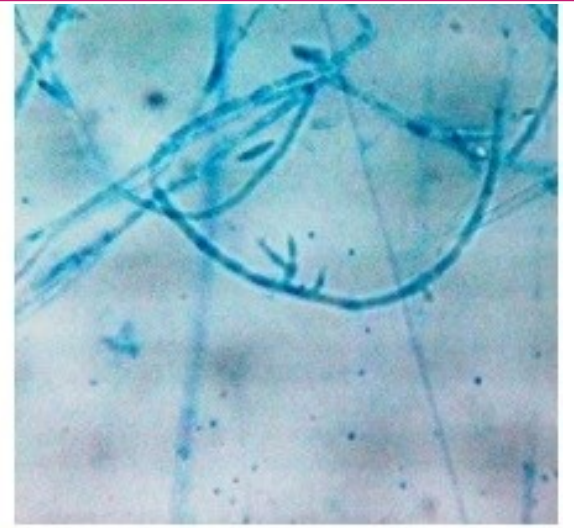

(C)

Fig. 2. Colony morphology of Fusarium pallidoroseum at 100X magnification (A) on PDA (B) sporodochia (C) Hyphae showing typical mesoconidia.

Orange to peach pigmentation around the colony on the reverse side of the Petridishes was also observed. After incubation at $28 \pm 2{ }^{\circ} \mathrm{C}$ temperature for 14 days, this isolate also produced definite sporodochia with macroconidia. Hyaline septate hyphae with buldged compartments, conidiophores and phialides were observed microscopically. Cylindrical phialides with small collaret was observed as a constituent of a complex branching system. Monophialides as well as polyphailides conditions, were observed. Macroconidia produced in sporodochia on phailides were long, 3-9 septate, sickle shaped, smooth and possess a significant foot cell. Those born in the aerial mycelium were slightly curved, 3-7 septate and without notched. Fusiform mesoconidia were also observed in the culture which looked like 'rabbit ears' were abundant in the aerial mycelia.

\section{Scanning electron microscopy}

A big mass of hyphae was observed together with macroconidia, mesoconidia and microconidia at 1000X and 3500X magnification examined by SEM. Infection hyphae with appresorium (measuring about $5.21 \mu \mathrm{m}$ ) were observed among the mycelial mat (Fig. $3 \mathrm{~A}$ ), along with the polyphialides (Fig. $3 \mathrm{~B}$ ) and chlamydospore (Fig. $3 \mathrm{C}$ ) at $6000 \mathrm{X}$ and $2500 \mathrm{X}$ magnification, separately. The length of macroconidia was found approximately $11.26 \mu \mathrm{m}$ (Fig. $3 \mathrm{D}$ ). Short spindle-shaped microconidia were also present. The mycelial organization revealed by SEM also showed an extracellular material around the hyphae which was seen as a flocculent material over the cells or as a fine fibrils attaching hyphae to each other, resembling a biofilm (Fig. $3 \mathrm{E}$ ). The round structure seen in Fig. $3 \mathrm{~F}$, under 2500X is a chlamydospore with a diameter of about $2.56 \mu \mathrm{m}$.

\section{Effect of different media}

The results on suitability of different synthetic and semisynthetic media in solid state on the growth and sporu- lation of the fungus are represented in Table 1.

The fungus grew rapidly on solid agar medium like Czapek-Dox medium, potato dextrose medium and MYEA medium as cottony flattened colonies with yellowish-orange sporulation and produces high number of macroconidia and microconidia. Spindle-shaped mesoconidia and microconidia were observed in the aerial mycelium. The potato dextrose agar medium recorded maximum mycelial growth $(80.00 \mathrm{~mm})$ followed by Czapek Doxagar medium $(77.66 \mathrm{~mm})$ and Coconut water agar medium (10\% coconut water) $(75.33 \mathrm{~mm})$. The characteristic growth pattern of fungus was not observed on coconut agar medium with $5-10 \%$ coconut water and agar medium but production of macroconidia was found maximum.

\section{Effect of temperature and $\mathrm{pH}$}

The optimum temperature for growth of $F$. pallidoroseum was found $28{ }^{\circ} \mathrm{C}$ (dry mycelial weight 264.51 $\mathrm{mg}$ ) followed by $32^{\circ} \mathrm{C}$ (dry mycelial weight $203.12 \mathrm{mg}$ ) and $24^{\circ} \mathrm{C}$ (184.43 $\left.\mathrm{mg}\right)$. The minimum dry mycelial weight was obtained at $40^{\circ} \mathrm{C}(92.47 \mathrm{mg})$ after fifteen days of inoculation which shows that higher temperature inhibited the growth of fungus (Graph 1 \& Table2).

The results revealed that the fungus could grow and sporulate in wide range of $\mathrm{pH}$, i.e., from $\mathrm{pH}-5.0$ to $\mathrm{pH}$ -9.0 , in liquid potato dextrose medium (Graph 1). The dry mycelial weight was significantly higher at $\mathrm{pH} 8.0$ (444.33mg) followed by $\mathrm{pH} 7$ (334.42 $\mathrm{mg}$ ) after fifteen days of inoculation. All the experimental data are significantly different from each other (Graph 2 \&Table: 3).

\section{Bio-efficacy of F. pallidoroseum against Helicover- pa armigera}

The research results showed that $F$. pallidoroseum could initiate infection on susceptible Helicoverpa larvae only when the host surface was injured. This indi- 

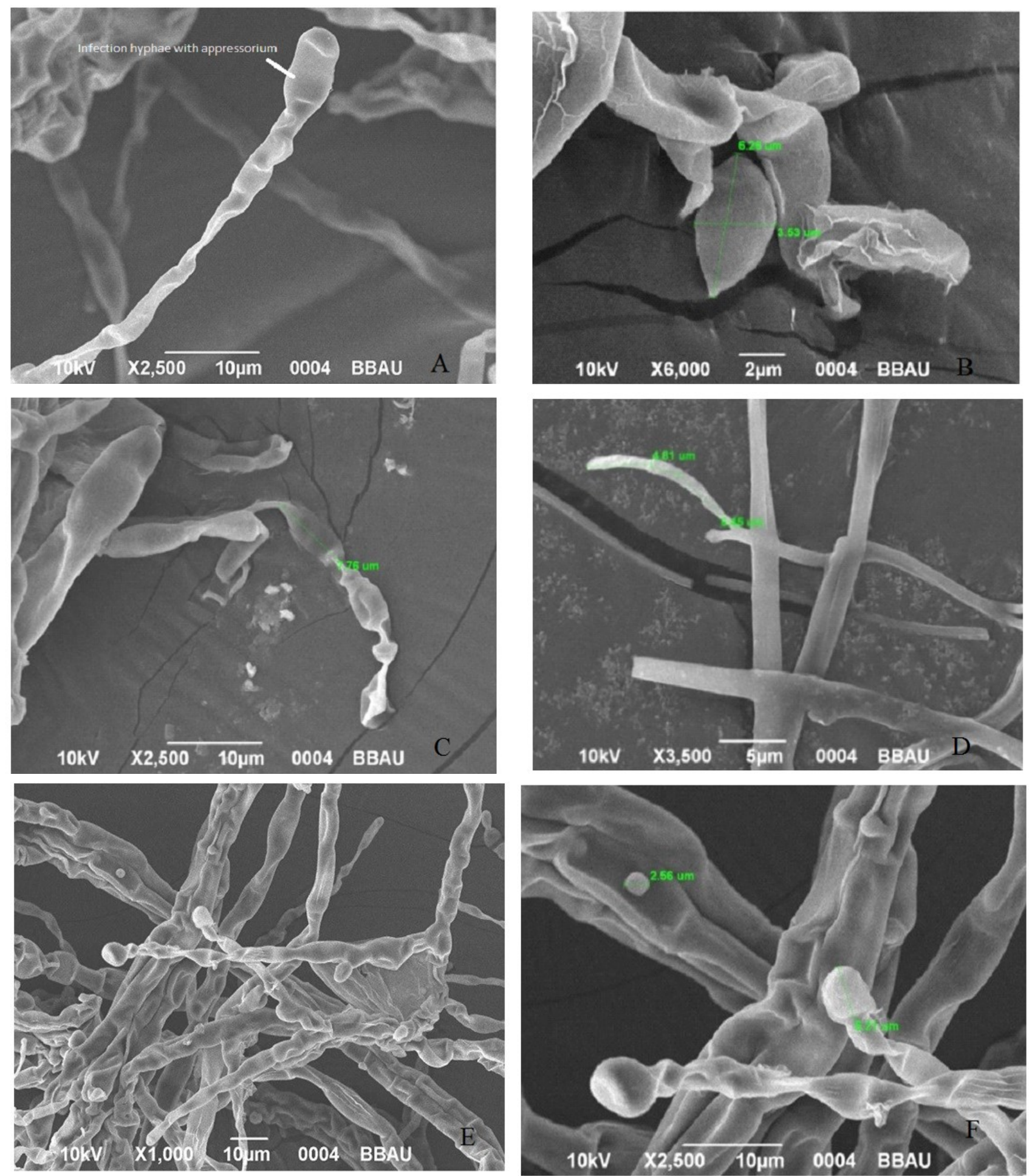

Fig. 3. Scan electron micrographs of $F$. pallidoroseum grown on PDA (A). Infection hyphyae with appresorium (B). Polyphialides (6000X) (C). Chlamydospore (2500X) and (D). Macroconidia (3500X) (E). An extracellular material around the hyphae (F). Microconidia and chlamydospores (2500X) .

cates that this is a weak pathogen of this pest.

\section{Bio-efficacy of F. pallidoroseum against Aphis gossypii}

Bio-efficacy studies on okra aphid, A. gossypii clearly indicate that this fungus might be used successfully for the control of $A$. gossypii in okra by incorporating it in integrated pest management strategies. Among the different fungal concentrations, the least per cent mortality of nymphs was noticed in $1 \times 10^{6}$ spore suspension $(46.67 \%)$ to $1 \times 10^{4}$ spore suspension $(36.6 \%)$ as against $93.33 \%$ in $1 \times 10^{10}$ spores per $\mathrm{mL}$ after 8 days after spraying (Graph 3 ). The result also revealed that two days after spray, all the treatments differed signifi- 
Table 1. Growth of Fusarium pallidoroseum on different solid media

\begin{tabular}{|c|c|c|c|c|}
\hline \multirow[t]{2}{*}{ Medium } & \multicolumn{2}{|c|}{ Conidia production } & \multirow[t]{2}{*}{ Colour of colony } & \multirow{2}{*}{$\begin{array}{l}\text { Radial growth after } \\
15 \text { days } \mathrm{mm} \text { ) }\end{array}$} \\
\hline & Macroconidia & Microconidia & & \\
\hline $\begin{array}{l}\text { Potato dextrose } \\
\text { agar }\end{array}$ & ++ & ++++ & $\begin{array}{l}\text { White wooly growth and orange } \\
\text { tan in reverse }\end{array}$ & $80.0 \pm 0.171$ \\
\hline Agar $2 \%$ & - & ++++ & Only white mycelium & $80.0 \pm 0.185$ \\
\hline $\begin{array}{l}\text { Czapek Dox Medi- } \\
\text { um (Difco and BBL) }\end{array}$ & ++ & +++ & $\begin{array}{l}\text { Orange cousin growth with yel- } \\
\text { lowish orange in reverse }\end{array}$ & $77.66 \pm 0.168$ \\
\hline $\begin{array}{l}\text { MYEA (malt yeast } \\
\text { extract) }\end{array}$ & + & +++ & $\begin{array}{l}\text { pink cousin growth with yellow- } \\
\text { ish orange in reverse }\end{array}$ & $72.33 \pm 0.159$ \\
\hline $\begin{array}{l}\text { Coconut water } 5 \% \\
\text { with agar }\end{array}$ & ++ & + & Only white mycelium & $67.00 \pm 0.188$ \\
\hline $\begin{array}{l}\text { Coconut water } 10 \% \\
\text { with agar }\end{array}$ & ++ & + & Only white mycelium & $75.33 \pm 0.196$ \\
\hline $\begin{array}{l}\text { Martin Agar medi- } \\
\text { um }\end{array}$ & + & ++ & $\begin{array}{l}\text { pink growth with yellowish or- } \\
\text { ange in reverse }\end{array}$ & $69 \pm 0.169$ \\
\hline $\begin{array}{l}\text { Molish Agar medi- } \\
\text { um }\end{array}$ & + & - & Only white mycelium & $22 \pm 0.086$ \\
\hline $\begin{array}{l}\text { Sabouraud Agar } \\
\text { medium }\end{array}$ & + & + & Only white mycelium & $31 \pm 0.121$ \\
\hline Richards medium & ++ & - & $\begin{array}{l}\text { Orange cousin growth with yel- } \\
\text { lowish orange in reverse }\end{array}$ & $5.8 \pm 0.001$ \\
\hline $\begin{array}{l}\text { Asthana \& Hawkers } \\
\text { medium }\end{array}$ & ++ & ++ & $\begin{array}{l}\text { White wooly growth and orange } \\
\text { tan in reverse }\end{array}$ & $72 \pm 0.173$ \\
\hline
\end{tabular}

Radial growth* each value is the mean of six replication and represented as mean \pm SE, Sporulation represented by $0-20 \%,+20$ $40 \%,++40-60 \%$, +++ $60-80 \%,++++80-100 \%$

Table 2. ANOVA for effect of different temperature on the growth of Fusarium pallidoroseum

\begin{tabular}{lllllll}
\hline Source of Variation & SS & df & MS & F & P-value & F crit \\
\hline Between Groups & 127648 & 7 & 18235.5 & 9.72688 & 0.00053 & 2.24902 \\
Within Groups & 74990.1 & 40 & 1874.75 & & & \\
Total & 202639 & 47 & & & & \\
\hline
\end{tabular}

Table 3. ANOVA for effect of media pH on the growth of Fusarium pallidoroseum.

\begin{tabular}{lllcccc}
\hline Source of Variation & SS & df & MS & F & P-value & F crit \\
\hline Between Groups & 196392 & 7 & 28056 & 4.8266 & 0.00085 & 2.31274 \\
Within Groups & 186009 & 32 & 5812.79 & & & \\
Total & 382401 & 39 & & & & \\
\hline
\end{tabular}

cantly with each other. Nymphs were more susceptible than adults. At six days after spraying, nymphs and adults showed sluggish movement, internal and external infection and profuse sporulation. A maximum of $93.33 \%$ mortality of nymphs and $66.67 \%$ adult mortality was recorded at $1 \times 10^{10}$ spores per $\mathrm{mL}$ concentration which were at par with other treatments. In general, an inclination in mortality was observed with advancement of time with most spore concentrations, indicating a linear positive association between mortality and days of observation. The other treatment also resulted in significantly higher mortality of $A$. gossypii nymphs and adults than the control.
Bioassays of $F$. pallidoroseum against the nymphs and adults of $A$. gossypii under laboratory conditions revealed a range of variation in their biological activity. Probit analysis of mortality data enabled calculation of the dose-response relationships for nymphs, obtaining the following equations and $\mathrm{LC}_{50}$ with $95 \%$ fiducial limits: $y=0.448 \pm 0.036-2.50, x^{2}=13.067$, and $3.79 \times 10^{5}$ spores/ $\mathrm{mL}$ (Fiducial limit $1.84 \times 10^{5}-7.12 \times 10^{5}$ ). The fit of the transformed data was acceptable using the chisquared test (Table 4).

We can conclude that the isolated entomopathogen has a high potential as a biological control agent in the strategic management of $A$. gossypii. Thus, it can be 
Table 4. Probit analysis of concentration-mortality response of the nymphs to $F$. pallidoroseum

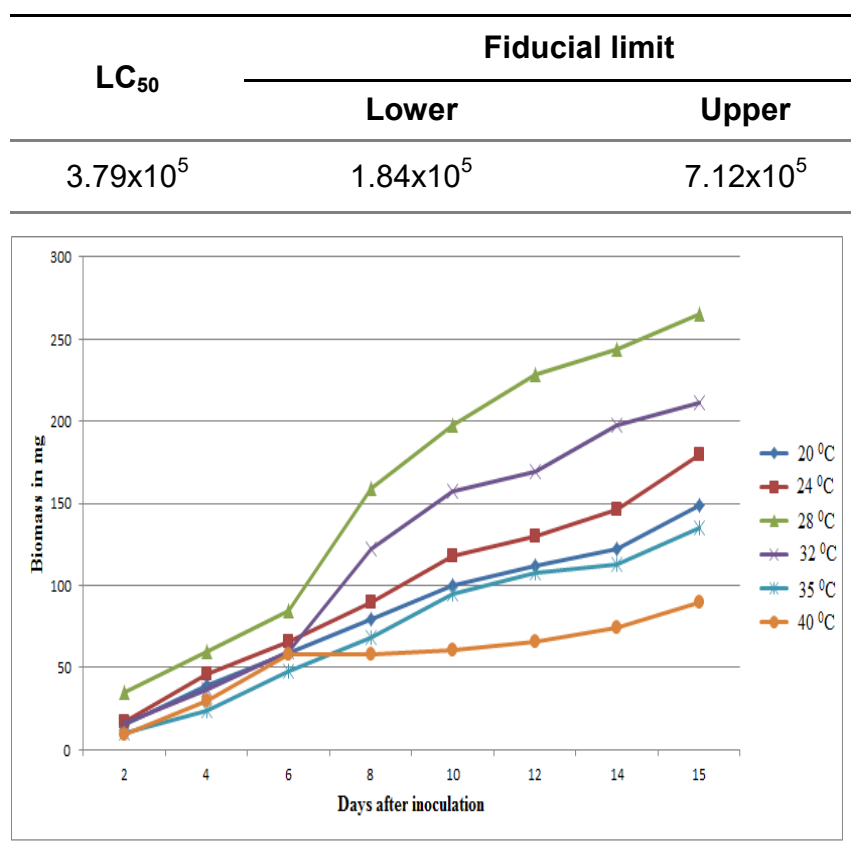

Graph 1. Effect of different temperature on the growth of F. pallidoroseum.

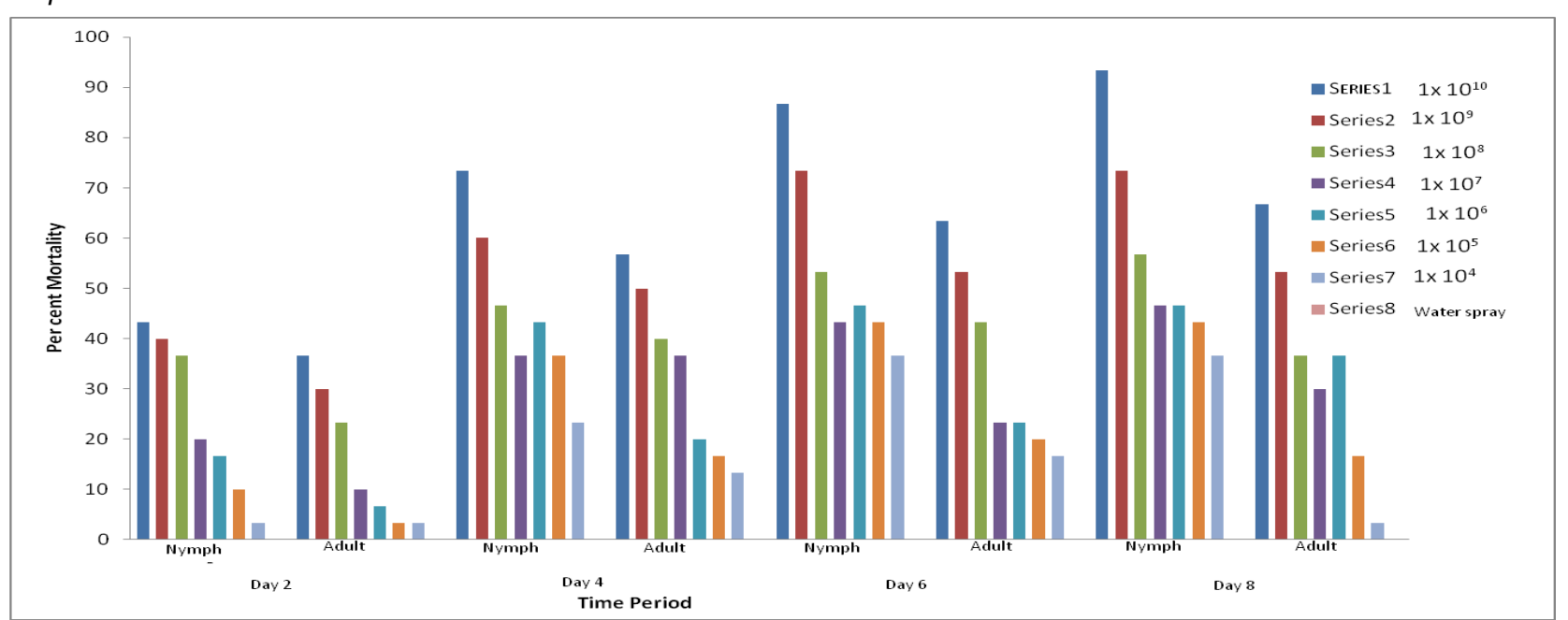

Graph 3. Efficacy of F. pallidoroseum on the nymphs and adults of A. gossypii.

inferred that further research is needed on the possibility of developing indigenous formulation by the application of synergists or diet enhancers in increasing its virulence under field conditions.

Literature revels that the researches on Fusarium against insects has led to the discovery of new species (Freeman et al., 2013a; Aoki et al., 2018; Aoki et al., 2019; da Silva et al., 2020) and of numerous remarkable interactions between Fusarium and insects (Freeman et al., 2013b; Kasson et al., 2013; O'Donnell et al., 2016; Toki et al.,2016) demonstrating that fungi often solely studied as plant pathogens could also play supplementary roles in nature for which we don't know the biological significance.

Further, many Fusarium species have been recorded to be competent in controlling agricultural insect pests; causing high mortality rates and having fast action and profuse sporulation (Ganassi et al., 2001; TorresBarragan et al., 2004; Munshi et al., 2008; Abdul-Wahid and Elbanna, 2012; Fan et al., 2015; Tosi et al., 2015; da Silva et al., 2016; Anwar et al., 2017; Velez et al., 2019; da Silva et al.,2020; Diniz et al., 2020; de Lima et al., 2021). Although, interactions of Fusarium spp as an entomopathogenic fungi have received greater attention in the recent years, but much remains to be explored as did in the current investigation.

\section{Scanning electron microscopy}

During current observation of SEM studies, appressoria formation by $F$. pallidoroseum is consistent with the 
findings of Nair and Corbin (1981). Direct penetration of cuticle via infection pegs (appressoria) might also be the mode of attack, as was evident from SEM study. The observation by SEM have already been recorded against different Fusarium spp. Similar result in SEM study was recorded in case of $F$. solani and $F$. oxysporum with the difference lieing in size and septation of macroconidia and microconidia facilitating taxonomic classification at the species level (Ciampi et al., 2009; Shahnazi et al., 2012; Husien, 2019).

\section{Effect of different media}

Similarly, it was revealed that potato dextrose agar medium supported the best growth of Trichoderma terrean, Colletotrichum gloeospiroides, Beaveria bassiana and F. pallidoroseum (Shehu and Ibrahim, 2014). Growth characters of $F$. oxysporum f. sp. gerberae studied on different solid media indicated that the growth was maximum on Oat meal agar followed by Richards's agar, Czapek's Dox agar, and Potato Dextrose agar supported maximum growth of fungal colony (Rajirani et al., 2000; Rajirani 2001; Chittem and Kulkarni, 2008; Mezzomo et al., 2018; Westphal et al., 2021). These studies revealed that among the solid substrates, leafy substrates, bran and oil seed cakes, and the liquid substrates tested mature coconut water supported maximum biomass and macrconidia. Increased virulence of spore suspensions prepared from coconut media was found due to the abundance of macroconida in them.

\section{Bio-efficacy of F. pallidoroseum against Aphis gossypii}

Field experiments conducted to estimate efficacy of $F$. pallidoroseum to manage $A$. craccivora using different spore formulations discovered that $82 \%$ mortality of mite, Calepitrimerus azadirachtae by $F$. samitectum at $2.3 \times 10^{9}$ spores per $\mathrm{mL}$ (Navik et al., 2015). A significantly enhanced proline level in plants infected by $F$. pallidoroseum also showed their role as plant growth promoter (Srivastava et al., 2011). Monga et al., 2010 also reported $F$. pallidoroseum to cause $80-95 \%$ mortality of cotton mealybug, Phenacoccus solenopsis Tinsley.

F. semitectum Berk and Ravenel was reported to be effective against many sucking pests viz., sugarcane wooly aphid, Ceratovacuna lanigera Zehntner (Aswini, 2007 and Nagaratha, 2004), on cowpea aphid, A. craccivora Koch (Roopa Rani, 2008) and tobacco aphid, Myzus persicae (Sulzer) (Asharani, 2009). Further, bioefficacy of Fusarium pallidoroseum against cowpea sucking pests such as Aphis craccivora and Riptortus pedestris was very effective entomopathogen against $A$. craccivora and $R$. pedestris respectively and showed consistently higher mortality with increase in the exposure time; however, against Beauveria bassiana and
Metarhizium anisopliae it was recorded moderately effective (Kavitha and Faizal, 2020; Singh and Kaur 2020; Tarekegn et al., 2020).

Furthermore, majority of the isolates of $F$. oxysporum species complex have also been tested against Lepidoptera insects the mortality rates recorded from low to high (Ali-Shtayeh, and Jamous, 2003; Sun and Liu, 2008; Baidoo and Ackuaku, 2011), and from moderate to high against insects of the orders Coleoptera and Hemiptera (Torres-Barrag_an et al., 2004; Qi et al., 2011; Ameen, 2012; Qi et al., 2016; Anwar et al., 2017; Sharma and Marques 2018).

These fungal bio-control agents would offer a new approach to combat natural population of insect pest, while protecting the efforts and investments of the marginal farmers (Lingappa et al., 2005; Freeman et al., 2013; Aoki et al., 2018; Sharma and Marques , 2018; da Silva et al., 2020).

\section{Conclusion}

The findings of the present investigation shows that spraying of spore formulation of Fusarium pallidoroseum, at $1 \times 10^{10}$ spores/ mL conc was the most effective against $A$. gossypii, recorded $93.33 \%$ mortality of nymphs and $66.67 \%$ mortality of adults; could be used under IPM practices. Further, after multilocational field trials as well as synergistic effects of the selected strains of $F$. pallidoroseum, in combination with selected chemicals and their toxicity to the target pests (i.e. still in progress); an effective, ecofriendly, cost effective biocontrol agent could be explored for transferring the technology to the farmers.

\section{ACKNOWLEDGEMENTS}

The authors are thankful to the Head- Department of Botany, University of Lucknow, Lucknow for providing the research facilities; and to the Department of Plant Pathology, Indian Agricultural Research Institute, New Delhi for providing the scientific expertise, during identification of the isolated fungal species. Besides, one of the author is also thankful to the Department of Science and Technology, New Delhi, India; for the financial assistance, under DST WOS- 'A' Project No. SR/ WOS-A/ LS-149/2013

\section{Conflict of interest}

The authors declare that they have no conflict of interest.

\section{REFERENCES}

1. Abdul-Wahid, O.A. \& Elbanna, S.M. (2012). Evaluation of the insecticidal activity of Fusarium solani and Trichoderma harzianum against cockroaches; Periplaneta America- 
na. African Journal of Microbiology Research, 6, 10241032. DOI:10.5897/ajmr-11-1300.

2. Ahmad, S. \& Ansari, M. S. (2013) Acute toxicity and sublethal effects of a pyrethroid (cypermethrin) on survival, development and fitness of Helicoverpa armigera. Archives of Phytopathology and Plant Protection 46, 1726-1739. https://doi.org/10.1017/S1742758413000246

3. Ali-Shtayeh, M. S., Mara'i, A. B. B. \& Jamous, R. M. (2003). Distribution, occurrence and characterization of entomopathogenic fungi in agricultural soil in the Palestinian area. Mycopathologia, 156(3), 235-244.

4. Ameen, M. K. M. (2012). Screening of Fusarium isolates pathogenicity in vitro by using the larvae of Galleria Mellonella L. Journal of Basrah Researches (Sciences), 38(3).

5. Anwar W, Haider MS, Shahid AA, Mushtaq H, Hameed U, Rehman MZU, Iqbal MJ. 2017. Genetic diversity of Fusarium isolated from members of Sternor rhyncha (Hemiptera): entomopathogens against Bemisia tabaci. Pakistan Journal of Zoology 49: 639645. [Crossref], [Web of Science $®$ ], [Google Scholar]

6. Aoki, T., Kasson, M.T., Berger, M.C., Freeman, S., Geiser, D.M. \& O'Donnell, K. (2018). Fusarium oligoseptatum sp. nov., a mycosymbiont of the ambrosia beetle Euwallacea validus in the Eastern US and typification of $F$. ambrosium. FUSE 1, 23e39. doi: 10.3114/fuse.2018.01.03

7. Aoki, T., Smith, J.A., Kasson, M.T., Freeman, S., Geiser, D.M.,Geering, A.D. \& O'Donnell, K. (2019). Three novel Ambrosia Fusarium Clade species producing clavate macroconidia known ( $F$. floridanum and $F$. obliquiseptatum) or predicted ( $F$. tuaranense) to be farmed by Euwallacea spp. (Coleoptera: Scolytinae) on woody hosts. Mycologia 1e17. https://doi.org/10.1080/00275514.2019.1647074

8. Asharani, Manjunatha, A., M., Mohan, I. Naik, Shivanna, B. K., Gayathridevi, S. \& Pradeep, S. (2009). Evaluation of fungal pathogen, Fusarium semitectum Berk and Ravenel against tobacco aphid under laboratory and greenhouse conditions. Karnataka Journal of Agricultural Sciences 22 (3-Spl. Issue), 495-498.

9. Aswini, G.V., Manjunatha, M. \& Mohan, I. Naik (2007). Evaluation of fungal pathogen, Fusarium semitectum Berk and Ravenel against sugarcane woolly aphid under laboratory and greenhouse conditions. Karnataka Journal of Agricultural Sciences 20(4), 767-770.

10. Baidoo, P.K. \& Ackuaku, S.K. (2011). The effects of spore concentrations of entomogenous fungi on larval mortality and development of the maize stem borer Eldana saccharina Walker (Lepidoptera: Pyralidae). J. Appl. Biosci. 47, 3221e3229. http://hdl.handle.net/123456789/11106

11. Chittem, K. \& Kulkarni, S. (2008). Effect of Media on the Growth of Fusarium oxysporum f. sp. gerberae and Fusarium oxysporum f. sp dianthi. Karnataka J. Agric. Sci. 21(2), 303-304.

12. Ciampi, L., Jaun Nissen, M., Venegas, E., Fuentes, R., Costa, M., Schobitz, R., Alvarez, D. \& Alvarado Pilar (2009). Identification of two species of Fusarium link that cause wilting of colored callas (Zantedeschiaa ethiopica L. Spreng.) cultivated under greenhouse conditions in Chile. Chilean Journal of Agricultural Research 69(4), 516-525.

13. da Silva Santos, A. C., Diniz, A. G., Tiago, P. V. \& de Oliveira, N. T. (2020). Entomopathogenic Fusarium species: a review of their potential for the biological control of insects, implications and prospects. Fungal Biology Reviews, 34(1), 41-57. https://dx.doi.org/10.1016/j.fbr.201 9.12.002

14. da Silva Santos, A. C., Oliveira, R. L. S., da Costa, A. F., Tiago, P. V. \& de Oliveira, N. T. (2016). Controlling Dactylopius opuntiae with Fusarium incarnatum-equiseti species complex and extracts of Ricinus communis and Poincianella pyramidalis. Journal of Pest Science, 89(2), 539547. https://doi.org/10.1007/s10340-015-0689-4

15. de Lima, I. J., Carneiro Leão, M. P., da Silva Santos, A. C., da Costa, A. F. \& Tiago, P. V. (2021). Production of conidia by entomopathogenic isolates of Fusarium caatingaense on different vegetable substrates. Biocontrol Science and Technology, 31(2), 206-218.

16. European and Mediterranean Plant Protection Organization (2006). Distribution maps of Quarantine pests, Helicoverpa armigera. On-line Retrieved from ww.eppo.org/ Quarantine/insects/Helicoverpaarmigera/HELIAR_ma p.ht m

17. Fan Y., Ortiz-Urquiza, A., Garrett, T., Pei1, Y. \& Keyhan, N.O. (2015). Involvement of a caleosin in lipid storage, spore dispersal, and virulence in the entomopathogenic filamentous fungus, Beauveria bassiana. Environmental Microbiology, 17(11), 4600-4614. https://doi.org/10.1 111/1462-2920.12990

18. Freeman, S., Protasov, A., Sharon, M., Mohotti, K.M., Eliyahu, M., Okon-Levy, N., Maymon, M. \& Mendel, Z., (2013a). Obligate feed requirement of Fusarium sp. nov., an avocado wilting agent, by the ambrosia beetle Euwallacea aff. fornicata. Symbiosis 58, 245e251.

19. Freeman, S., Sharon, M., Maymon, M., Mendel, Z., Protasov, A., Aoki, T., Eskalen, A., O'Donnell, K., (2013b). Fusarium euwallaceae sp. nov.-a symbiotic fungus of Euwallacea sp., an invasive ambrosia beetle in Israel and California. Mycologia 105, 1595e1606. https:// doi.org/10.3852/13-066

20. Ganassi, S., Moretti, A., Stornelli, C., Fratello, B., Bonvicini Pagliai, A.M., Logrieco, A. \& Sabatini, M.A. (2001). Effect of Fusarium, Paecilomyces and Trichoderma formulations against aphid Schizaphis graminum. Mycopathologia 151, 131e138.

21. Ghosal, A., Chatterjee, M. L. \& Manna, D. (2012). Studies on some insecticides with novel mode of action for the management of tomato fruit borer (Helicoverpa armigera Hub.). Journal of Crop and Weed, 8(2), 126-129.

22. Gonçalves Diniz, A., Barbosa, L. F. S., Santos, A. C. D. S., Oliveira, N. T. D., Costa, A. F. D., Carneiro-Leão, M. P., \& Tiago, P. V. (2020). Bio-insecticide effect of isolates of Fusarium caatingaense (Sordariomycetes: Hypocreales) combined to botanical extracts against Dactylopius opuntiae (Hemiptera: Dactylopiidae). Biocontrol Science and Technology, 30(4), 384-395. https:// doi.org/10.1080/09583157.2020.1720601

23. Husien, H. (2019). Isolation, Identification, Pathogenicity bioassay and Mass production of Indigenous Isolate of Entomopathogenic Fungi against Red Palm Weevil Rhynchophorus ferrugineus (Olivier) (Coleoptera: Curculionidae) (Doctoral dissertation, Palestine Technical University-Kadoorie).

24. Hussain, A. (2007). Efficacy of some synthetic and biopesticides against pod borer. Agricultural Research and Extension pp 10.

25. Jarrahi, A. \& Safavi, S. A. (2016). Fitness costs to Heli- 
coverpa armigera after exposure to sub-lethal concentrations of Metarhizium anisopliae sensu lato: Study on F1 generation. Journal of invertebrate pathology, 138, 50-56. http://www.sciencedirect.com/science/article/pii/S00222 01116300556

26. Javed K, Javed H, Mukhtar T \& Qiu D. (2019). Pathogenicity of some entomopathogenic fungal strains to green peach aphid, Myzus persicae Sulzer (Homoptera: Aphididae). Egypt J Biol Pest Control. 29(92), 1-7. https:// doi.org/10.1186/s41938-019-0183-z

27. Jayasimha, G.T., Rachana, R.R., Rajkumar, V.B. \& Manjunatha M (2012). Evaluation of fungal pathogen, Fusarium semitectum Berk and Ravenel against okra aphid, Aphis gossypii Glover under laboratory and green house conditions. Pest Management in Horticultural Ecosystems 18(2), 139-142.

28. Kalvnadi, E., Mirmoayedi, A., Alizadeh, M., \& Pourian, H. R. (2018). Sub-lethal concentrations of the entomopathogenic fungus, Beauveria bassiana increase fitness costs of Helicoverpa armigera (Lepidoptera: Noctuidae) offspring. Journal of invertebrate pathology, 158, 32-42. http://dx.doi.org/10.1016/j.jip.2018.08.012

29. Kasson, M.T., O'Donnell, K., Rooney, A.P., Sink, S. Ploetz, R.C.,Ploetz, J.N., Konkol, J.L., Carrillo, D., Freeman, S., Mendel, Z.,Smith, J.A., Black, A.W., Hulcr, J., Bateman, C., Stefkova, K.,Campbell, P.R., Geering, A.D.W., Dann, E.K., Eskalen, A., Mohotti, K., Short, D.P.G., Aoki, T., Fenstermacher, K.A., Davis, D.D. \& Geiser, D.M., (2013). An inordinate fondness for Fusarium: phylogenetic diversity of fusaria cultivated by ambrosia beetles in the genus Euwallacea on avocado and other plant hosts. Fungal Genet. Biol. 56, 147e157. https:// doi.org/10.1016/j.fgb.2013.04.004

30. Kavitha, S.J. \& Faizal MH (2020). Bio-efficacy of entomopathogens on major sucking pests in cowpea (Vigna unguiculata L.). Journal of Entomology and Zoology Studies, 8(4), 694-698.

31. Khating SS, Kabre GB \& Dhainje A.A. (2016). Seasonal incidence of sucking pests of okra along with natural enemies in Khandesh region of Maharashtra. Asian Journal of Biosciences, 11(2), 269-272. DOI : 10.15740/HAS/ AJBS/11.2/269-272.

32. Lingappa, S., Saxena, H. \& Devi Vimala, P.S. (2005). Role of biocontrol agents in management of Helicoverpa armigera (Hubner). In: Hem Saxena, A. B. Rai, R. Ahmad and Sanjeev Gupta eds. Recent advances in Helicoverpaarmigera Management. Indian Society of Pulses Research and development, IIPR, Kanpur, pp 159-184.

33. Litwin, A., Nowak, M. \& Rozalska, S. (2020) Entomopathogenic fungi: unconventional applications. Rev Environ Sci Biotechnol 19, 23-42. https://doi.org/10.1007/s11157020-09525-1

34. Mehrvar, A., Rabindra, R.J., Veenakumari, K. \& Narabenchi, G.B. (2008). Molecular and biological characteristics of some geographic isolates of nucleopolyhedrovirus of Helicoverpa armigera (Lepidoptera: Noctuidae). Journal of Entomological Society of Iran 28, 39-60.

35. Mezzomo, R., Rolim, J.M., Poletto, T., de Oliveira, M.B., Lazarotto, M., Fátima, M. \& Brião Muniz (2018). Mycelial growth and sporulation of fusarium spp. pathogenic to ilex paraguariensis in different culture media and under exposure to different light levels. Scientia Agraria 19(1),14.
DOI: $10.5380 /$ rsa.v19i1.55844.

36. Mishra, K., Singh, K. \& Tripathi CPM (2013). Management of pod borer (Helicoverpa armigera) infestation and productivity enhancement of gram crop (Cicer aritenium) through vermiwash with biopesticides. World Journal of Agricultural Sciences, 9(5), 401-408. DOI: 10.5829/ idosi.wjas.2013.9.5.1749

37. Mohammed AA, Kadhim JH \& Kamaluddin ZNA (2018). Selection of highly virulent entomopathogenic fungal isolates to control the greenhouse aphid species in Iraq. Egypt J Biol Pest Control 28(71), 1-7. https:// doi.org/10.1186/s41938-018-0079-3

38. Monga, D., Kumhar, K.C. \& Kumar, R. (2010). Record of Fusarium pallidoroseum (Cooke) Sacc. on Cotton Mealybug, Phenacoccus solenopsis Tinsley. Journal of Biological Control, 24(4), 366-368. https://doi.org/10.18311/ jbc/2010/3588

39. Mora MAE, Castilho AMC \& Fraga ME (2017). Classification and infection mechanism of entomopathogenic fungi. Arq Inst Biol 84, 1-10. https://doi.org/10.1590/18081657000552015

40. Munshi, N.A., Barkat, Hussain, Malik, G.N., Musavir, Yousuf. \& Fatima, N. (2008). Efficacy of entomopathogenic fungus Fusarium pallidoroseum (Cooke) Sacc. against Gypsy moth (Lymantria obfuscate Walker). Journal of Entomology 5, 59-61. DOI: 10.3923/je.2008.59.61

41. Nagamandla, R.S., Jha, S. \& Latha N.S. (2017) Insect pests of tomato and their weather relations under open and cover cultivation. Int J Curr Microbiol Sci 6(9), 368375. https://doi.org/10.20546/ijcmas.2017.609.046

42. Nair, J. \& Corbin, J.B. (1981). Histopathology of Pinusradiata seedling infected by Colletotrichumacutatum f. sp. pinea. Phytopathology 71(8), 777-783.

43. Navik, O.S., Manjunatha, M., Kumaraswamy, M.C. \& Latha, M. (2015). Efficacy of entomoathogenic fungi and acaricidal molecules on mite, Calepitrimerus azadirachtae Channa Basavanna (Acari: Eriophyidae) on neem. Journal of Eco-friendly Agriculture 10(1), 53-57.

44. Nazir, T., Basit, A., Hanan, A., Majeed, M.Z. \& Qiu, D. (2019). In vitro pathogenicity of some entomopathogenic fungal strains against green peach aphid Myzus persicae (Homoptera: Aphididae). Agron, 9(7), 1-12. https:// doi.org/10.3390/agronomy9010007.

45. O'Donnell, K., Libeskind-Hadas, R., Hulcr, J., Bateman, C.,Kasson, M.T., Ploetz, R.C., Konkol, J.L., Ploetz, J.N., Carrillo, D.,Campbell, A., Duncan, R.E., Liyanage, P.N.H., Eskalen, A.,Lynch, S.C., Geiser, D.M., Freeman, S., Mendel, Z., Sharon, M., Aoki, T., Coss_e, A.A. \& Rooney, A.P. (2016). Invasive Asian Fusariume Euwallacea ambrosia beetle mutualists pose a serious threat to forests, urban landscapes and the avocado industry. Phytoparasitica 44, 435e442. https://doi.org/10.1007/s12600-016-0543-0

46. Patel DR \& Purohit MS.(2013). Influence of different weather parameters on aphid, Melanaphis sacchari infesting kharif Sorghum. International Journal of Plant Protection 6(2), 484-486. http://www.researchjournal.co.in/ online/IJPP.htm

47. Pawar, V.M. \& Borikar, P.S. (2005). Microbial options for the management of Helicoverpaarmigera (Hubner) In: "Recent Advances in Helicoverpa Management (Hem Saxena, A. B. Rai, R. Ahmad and Sanjeev Gupta eds.) Indian Society of Pulses Research and Development, 
Srivastava, R. and Shukla, A. C. / J. Appl. \& Nat. Sci. 13(2), 775 - 785 (2021)

IIPR, Kanpur, pp 193-231.

48. Qi, H., Wang, J., Endoh, R., Takeuchi, Y., Tarno, H. \& Futai, K. (2011). Pathogenicity of microorganisms isolated from the oak platypodid, Platypus quercivorus (Murayama) (Coleoptera: Platypodidae). Appl. Entomol. Zool. 46, 201e210.

49. Qi, J., Aiuchi, D., Tani, M., Asano, S. I. \& Koike, M. (2016). Potential of entomopathogenic Bacillus thuringiensis as plant growth promoting rhizobacteria and biological control agents for tomato Fusarium wilt. Int J Environ Agric Res, 2(6), 55-63.

50. Rajirani, O.P. (2001). Production and evaluation of the fungus, Fusarium pallidoroseum (Cooke) Sacc. As biopesticide against pea aphid, Aphis craccivora Koch. PhD thesis. Kerala Agricultural University, Thrissur, pp. 136.

51. Rathee, M. \& Dalal, P. (2018). Emerging Insect Pests in Indian Agriculture. Indian Journal of Entomology, 80(2), 267-281. DOI No.: 10.5958/0974-8172.2018.00043.3

52. Rejirani, O.P., Mathai, S. \& Peethambaran, C.K. (2000). Evaluation of different naturally available substrates for mass production of the entomopathogenic fungus, Fusarium pallidoroseum (Cooke) Sacc. In: Proceedings of the $12^{\text {th }}$ Kerala Science Congress, Thiruvananthpuram, pp. 27-29.

53. Rombach, M.C., Aguda, R.M., Shepard, B.M. \& Roberts, D.W. (1986). Infection of rice brown plant hopper, Nilaparvata lugens (Homoptera: Delphacidae), by field application of entomopathogenic Hyphomycetes (Deuteromycot ina). Environmental Entomology 15, 1070-1073. DOI:10.1093/EE/15.5.1070

54. Roopa Rani, V. (2008). Bio ecology of aphid, Aphis craccivora Koch and evaluation of fungal pathogen, Fusarium semitectum Berk and Ravenel against cowpea aphid. $M$. Sc. (Agri.) Thesis. University of Agricultural Sciences, Bangalore (India)

55. Statistical Analysis System (2002). SAS Software: Version 9.1.SAS Institute, Cary, NC

56. Sasidharan, K.R. \& Varma, R.V. (2005). Laboratory evaluation of Beauveria bassiana (Balsamo) Vuillemin against Indrabela quadrinata Walker (Lepidopteron: Metarbelidae) a key pest of Casuarina equisetifolia L. in Tamil Nadu. Journal of Biological Control, 19, 197-200

57. Shahnazi, S., Meon, S., Vadamalai, G., Ahmad, K. \& Nejat, N. (2012). Morphological and molecular characterization of Fusarium spp. associated with yellowing disease of black pepper (Piper nigrum L.) in Malaysia. J Gen Plant Pathol 78, 160-169. DOI 10.1007/s10327-012-0379-5.

58. Sharma, L., \& Marques, G. (2018). Fusarium, an entomopathogen-A myth or reality?. Pathogens, 7(4), 93. doi:10.3390/pathogens 7040093

59. Shehu, K. \& Ibrahim, M. (2014). Influence of culture media and light regimes on the growth of Helminthosporium fulvum. The Experiment 27(2), 1863-1866.

60. Shophiya, J., Nancy, Sahayaraj, K., Kalaiarasi, J.M.V. \& Shirlin Jebitta M. (2014). Biocontrol potential of entomopathogenic fungus Beauveria bassiana (balsamo) against Pericalliaricini (Fab.) (Lepidoptera: Arctiidae) larvae. Biolife 2(3), 813-824

61. Singh, H. \& Kaur, T. (2020). Pathogenicity of entomopathogenic fungi against the aphid and the whitefly species on crops grown under greenhouse conditions in India. Egypt J Biol Pest Control 30 (84). https://doi.org/10.1186/s41938 -020-00287-0

62. Singh, N. \& Dhiman S. (2018). Quality and quantity loss by aphid infestation in vegetable crops grown under protected cultivation in Ladakh region. Defense Life Science Journal, 3(1), 71-74. DOI : 10.14429/dlsj.3.11516

63. Srivastava, S., Singh, V.P., Kumar, R., Srivastava, M., Sinha, A. \& S Simon (2011). In vitro evaluation of carbendazim 50\% WP, antagonists and botanicals against Fusarium oxysporum f. sp. psidii associated with rhizosphere soil of guava. Asian Journal of Plant Pathology, 5 (1), 46-53. http://dx.doi.org/10.3923/ajppaj.2011.46.53

64. Sun, B. D., \& Liu, X. Z. (2008). Occurrence and diversity of insect-associated fungi in natural soils in China. Applied soil ecology, 39(1), 100-108.

65. Tarekegn Fite, Tadele Tefera, Mulugeta Negeri, Tebekew Damte \& Waktole Sori (2020) Evaluation of Beauveriabassiana, Metarhiziumanisopliae and Bacillus thuringiensis for the management of Helicoverpaarmigera (Hubner) (Lepidoptera: Noctuidae) under laboratory and field conditions, Biocontrol Science and Technology, 30(3), 278-295, DOI: 10.1080/09583157.2019.1707481

66. Toki, W., Kawakita, A. \& Togashi, K. (2016). Presence of weed fungus in a non-social beetleefungus cultivation mutualism. Ecol. Entomol. 41, 253e262. DOI: 10.1111/ een.12293

67. Torres-Barrag_an, Anaya, A.L., Alatorre, R., Toriello, C. (2004). Entomopathogenic fungi from 'El Eden' Ecological Reserve, Quintana Roo, Mexico. Mycopathologia 158, 61e71. https://doi.org/10.1023/B:MYCO.0000038424.013 6 $9 . c 8$

68. Tosi, L., Beccari, G., Rondoni, G., Covarelli, L. \& Ricci, C. (2015). Natural occurrence of Fusarium proliferatum on chestnut in Italy and its potential entomopathogenicity against the Asian chestnut gall wasp Dryocosmus kuriphilus. J. Pest. Sci. 88, 369e381. https://doi.org/10.1007/ s10340-014-0624-0

69. Velez, de A.,, Augusto, B., Diniz, A. G., Barbosa, L. F. S., da Silva Santos, A. C., da Costa, A. F., \& Tiago, P. V. (2019). Potential of Fusarium incarnatum-equiseti species complex isolates with Chenopodium ambrosioides and Enterolobium contortisiliquum extracts to control Dactylopius opuntiae. International Journal of Tropical Insect Science, 39(2), 131-138. https://doi.org/10.1007/s42690-01900014-9

70. Westphal, K.R., Heidelbacha, S., Zeuner, E.J., Jensena, M.R., Nielsen, M.E., Vestergaarda, S.Z., Bekker, N.S., Skovmark, J., Olesen, C.K., Thomsen, K.H., Niebling, S.K., Sørensen, J.L. \& Sondergaard, T.E. (2021). The effects of different potato dextrose agar media on secondary metabolite production in Fusarium. International Journal of Food Microbiology 347(2).00.000. https:// doi.org/10.1016/j.jijoodmicro.2021.109171

71. Yaqoob Munazah, Qurat ul Ain \& Ayoub Liyaqat (2019). Seasonal incidence of aphid, Aphis gossypii infesting okra and its relation with weather parameters. Journal of Entomology and Zoology Studies, 7(4), 672-674. 